\title{
Kudzu Response to Foliar Applied Herbicides
}

\author{
Mark A. Weaver, Robert E. Hoagland, C. Douglas Boyette \\ United States Department of Agriculture, Agricultural Research Service, Southern Weed Science Research Unit, \\ Stoneville, USA \\ Email: $\underline{\text { mark.weaver@ars.usda.gov }}$
}

Received 16 January 2015; accepted 6 April 2015; published 13 April 2015

Copyright (C) 2015 by authors and Scientific Research Publishing Inc.

This work is licensed under the Creative Commons Attribution International License (CC BY). http://creativecommons.org/licenses/by/4.0/

c) (i) Open Access

\begin{abstract}
Chemical control is presently the most cost-effective means to control kudzu; however, some of the herbicides labeled for kudzu control have substantial non-target toxicity, poor selectivity, high cost, long soil persistence, high soil mobility and/or high use rates. The present study evaluated other herbicides for efficacy in suppressing aboveground kudzu biomass in replicated field trials at three sites over two years. A single application of aminopyralid, triclopyr or metsulfuron resulted in at least $\mathbf{9 0 \%}$ kudzu suppression in the following season at two locations. After a second year of treatment those herbicides and fluroxypyr produced at least $\mathbf{9 0 \%}$ kudzu suppression, and $\mathbf{1 0 0 \%}$ kudzu control was reached on some test plots. Glyphosate, glufosinate and mesotrione were less effective in controlling kudzu. Given the rapid growth potential of kudzu, complete eradication should be pursued. None of the herbicides evaluated in the present study could reliably achieve eradication of mature kudzu with two applications, so additional control efforts would be required.
\end{abstract}

\section{Keywords}

Herbicidal Control, Invasive Species, Pueraria montana var. lobata, Weed Control

\section{Introduction}

Kudzu (Pueraria montana var. lobata) is a perennial vine that is exceptionally well adapted to the southeastern United States due to several unique physiological traits, the ability to fix atmospheric nitrogen, and the lack of significant indigenous pathogens or parasites. Recognizing this fitness, kudzu was extensively planted in the early 1900s by conservationists, farmers, homeowners and government agencies. Today, kudzu is among the worst invasive weeds in the world. It infests 3 million hectares in the United States, and more significantly, it is 
colonizing an additional 50,000 hectares annually. Throughout kudzu's present and expanding range, it is devastating natural ecosystems. Kudzu is an expensive nuisance to managers of utility lines. It is also a host of Asian Soybean Rust and exacerbates forest fires [1]-[3]. Just within the state of Mississippi, an estimated \$54 million dollars are lost annually as a result of kudzu invasion of timber plantations [4].

Sustained overgrazing, solarization or mechanical removal can suppress kudzu, although each of these approaches presents significant challenges of its own [1] [5]. There has been a significant and ongoing search for an effective exotic [6] [7] or indigenous [8] biological control agent, but no satisfactory agent has yet been widely deployed. Thus, herbicidal control is the most commonly used management strategy.

Picloram and tebuthiuron containing herbicides are commonly recommended for kudu control. The scientific basis for these recommendations comes, in a large part, from a series of papers by Miller in the 1980s [9]-[11] and these guidelines are reflected in more recent publications (e.g., [12] [13]). Everest et al. [1] in 1999 also recommended picloram and tebuthiuron containing herbicides, but cautioned that retreatments might be necessary for up to 10 years. After evaluating 25 herbicides over 8 years, Miller [14] acknowledged that other herbicides might be warranted in some site-specific cases, but that the products other than Tordon [picloram] were less effective. Picloram, however, has several significant limitations. It is a restricted use product and requires specialized training for commercial applicators. Picloram, which is persistent in soil, is mobile in groundwater [15] and has significant non-target toxicity. Tebuthiuron is also persistent in the environment and is so non-selective that it is labeled for "total control of brush and weeds". More recently, aminocyclopyrachlor and aminopyralid have become commercially available and have been evaluated for management of kudzu [16]. Aminopyralid is especially interesting, as this herbicide is highly selective and may facilitate plant community succession to more desirable vegetation. Milestone, one commercial formulation of aminopyralid, is labeled for use on land enrolled in Conservation Reserve Program (CRP), natural areas and wildlife clearings, where few other products are explicitly permitted. The southeastern state of Mississippi, Alabama and Georgia have more than 500,000 ha of CRP [17] land and many natural or minimally managed areas that are susceptible to kudzu invasion. Other herbicides with much lower use rates, fewer use restrictions, greater selectivity and compatibility with other management approaches would be of great value in a more integrated and environmentally responsible kudzu eradication program [18].

The objective of this research was to assess the level of control of kudzu by several commercially available, selective, foliar applied, non-restricted use herbicides in controlled, replicated field trials within naturally occurring stands of kudzu.

\section{Materials and Methods}

\subsection{Study Sites}

Three kudu-infested sites within Mississippi, USA were selected for field research. The Eden site $\left(33^{\circ} 0^{\prime} 16.73^{\prime \prime} \mathrm{N}\right.$ $90^{\circ} 15^{\prime} 56.11^{\prime \prime}$ ) occurs on the slopes near the edge of the Mississippi Alluvial Delta. The Mound Bayou site $\left(33^{\circ} 52^{\prime} 53.79^{\prime \prime} \mathrm{N} 90^{\circ} 36^{\prime} 44.71 \mathrm{~W}\right)$ is on a river terrace on the west bank of the Sunflower river. The Grenada $\left(33^{\circ} 55^{\prime} 2.00^{\prime \prime} \mathrm{N} 89^{\circ} 44^{\prime} 42.17^{\prime \prime} \mathrm{W}\right)$ site is in the Holly Springs National Forest, in the northern right-of-way of Highway 7. The three plots together span a distance of about $110 \mathrm{~km}$. The Eden and Mound Bayou experimental sites were initiated in 2007, and work began at the Grenada site in 2008. For consistency and reproducibility, all plots were established on flat to minor slopes with little or no competition from surrounding trees within mature kud$\mathrm{zu}$ monocultures. Mowed borders, $2 \mathrm{~m}$ wide, were maintained around each plot, which measured $2 \mathrm{~m}$ by approximately $15 \mathrm{~m}$. These borders were mowed every 7 to 14 days during the growing season, as needed, to minimize above ground spread of kudzu between plots. Meteorological observations were collected from local weather stations and are available at http://www.DeltaWeather.MsState.Edu/.

\subsection{Herbicide Application}

The herbicides evaluated in this study, their commercial formulations, and application rates are listed in Table 1. Because some products recommend the addition of spray adjuvants, Silwet L-77 was added to all products at a rate of $0.25 \%(\mathrm{v}: \mathrm{v})$. All applications were made with an ATV-mounted boomless, single-nozzle system (TeeJet TFW-12) calibrated to deliver a total volume of $374 \mathrm{~L} \cdot \mathrm{ha}^{-1}$ via two overlapping, counter-directional passes. Each treatment was replicated on 3 plots at each location and arrayed in a randomized complete block design. 
Table 1. Herbicides evaluated for kudzu control.

\begin{tabular}{ccccc}
\hline Herbicide & Commercial product tested & WSSA MoA $^{1}$ & Labeled uses $^{2}$ & Application rate $^{3}$ \\
Aminopyralid & Milestone & 4 & A, B, C, D & $0.51 \mathrm{~L} \cdot \mathrm{ha}^{-1}(0.14 \%)$ \\
Clopyralid & Transline & 4 & $\mathrm{~A}, \mathrm{~B}, \mathrm{C}, \mathrm{E}$ & $1.56 \mathrm{~L} \cdot \mathrm{ha}^{-1}(0.4 \%)$ \\
Fluroxypyr & Vista & 4 & $\mathrm{~B}, \mathrm{E}$ & $3.12 \mathrm{~L} \cdot \mathrm{ha}^{-1}(0.8 \%)$ \\
Fluroxypyr + triclopyr & PastureGard & 4 & $\mathrm{~A}$ & $9.35 \mathrm{~L} \cdot \mathrm{ha}^{-1}(2.5 \%)$ \\
Glufosinate & Ignite & 10 & $\mathrm{~F}, \mathrm{G}$ & $2.05 \mathrm{~L} \cdot \mathrm{ha}^{-1}(0.55 \%)$ \\
Glyphosate & Touchdown, Touchdown-HiTECH & 9 & $\mathrm{~A}, \mathrm{~B}, \mathrm{C}, \mathrm{D}, \mathrm{E}, \mathrm{F}$ & $9.34 \mathrm{~L} \cdot \mathrm{ha}^{-1}(2.5 \%)$ \\
Mesotrione & Calisto & 27 & $\mathrm{G}$ & $0.219 \mathrm{~L} \cdot \mathrm{ha}^{-1}(0.06 \%)$ \\
Metsulfuron & Escort & 2 & $\mathrm{~B}, \mathrm{E}$ & $280 \mathrm{~g} \cdot \mathrm{ha}^{-1}(0.75 \%)$ \\
Triclopyr & RemedyUltra & 4 & $\mathrm{~A}, \mathrm{D}$ & $9.35 \mathrm{~L} \cdot \mathrm{ha}^{-1}(2.5 \%)$ \\
\hline
\end{tabular}

${ }^{1}$ Weed Science Society of America Mechanism of action. ${ }^{2}$ Some representative labeled uses of the product: $\mathrm{A}=$ rangeland and pasture; $\mathrm{B}=$ roadsides or rights-of-way; $\mathrm{C}=$ natural areas or wildlife openings; $\mathrm{D}=$ conservation reserve program lands; $\mathrm{E}=$ select forestry sites; $\mathrm{F}=$ certain genetically modified crops; $\mathrm{G}$ = select row crop applications. Note: the same active ingredients are available in other commercial products with other labeled uses. ${ }^{3}$ Application rate determined by the label directions and expressed as formulated.

Applications were made on July 25, 2007 (Eden), Sept. 21, 2007 (Mound Bayou), July 14, 2008 (Eden), July 16, 2008 (Mound Bayou) and July 18, 2008 (Grenada). Mesotrione and glufosinate were dropped from the study after seeing limited control 11 months after treatment. Similarly, glyphosate was discontinued after the first application and subsequent observations at the Eden site. Due to limited product availability, the triclopyr plus fluroxypyr combination treatment was replaced with a clopyralid treatment after the first season at Mound Bayou. In 2008 clopyralid was applied to untreated plots at the Eden site, alongside the second year of application of the other herbicides.

\subsection{Measurement of Herbicide Efficacy}

All green kudzu biomass was collected in pre-weighed bags from a $0.3 \mathrm{~m}^{2}$ area, arbitrarily selected within each plot. In plots with very good control, multiple sampling grid placements were necessary to avoid false reporting of $100 \%$ control. The biomass was air-dried and the level of control was evaluated based on comparison to the biomass from surfactant-only control treatments. Evaluations were made at 14 days, 28 days and 11 months after the initial treatments and 11 months after the applications in the second year of treatment. Determination of the herbicidal efficacy and level of significance was via the proc mixed function of SAS v9.1 (SAS Institute, Cary, NC, USA) using a least significant difference of 0.05 .

\section{Results and Discussion}

\subsection{Eden Test Results}

The Eden experimental location was very nearly a pure monoculture of kudzu during midsummer of 2007, as is typical of mature kudzu infestations. Fourteen days after the initial application, all of the tested herbicides produced greater that $60 \%$ brown-out (Figure 1). Greater differences emerged between treatments at 28 days after treatment. After producing some moderate initial "bleaching" symptoms, the effect of mesotrione diminished. In contrast, aminopyralid, fluroxypyr, triclopyr and metsulfuron approached $100 \%$ aboveground suppression of kudzu, with a few plots containing zero green tissue. Nearly one year after the initial treatment, those same treatments were still providing strong kudzu suppression while the effect of glufosinate was less than $10 \%$ reduction while glyphosate and mesotrione providing slightly better results. The selectivity of the herbicides was evidenced by the strong emergence of other vegetation, especially little barley (Hordeum pusillum Nutt.) and Italian ryegrass (Lolium perenne L. ssp. multiflorum (Lam.) Husnot) (data not shown). The aforementioned herbicides, with the exceptions of mesotrione and glufosinate, were reapplied to the same plots in 2008. Clopyralid was also introduced in the study. The level of control noted the following season (summer, 2009) was generally less than observed after the first season of treatment but still over $80 \%$ suppression. Clopyralid provided slightly 


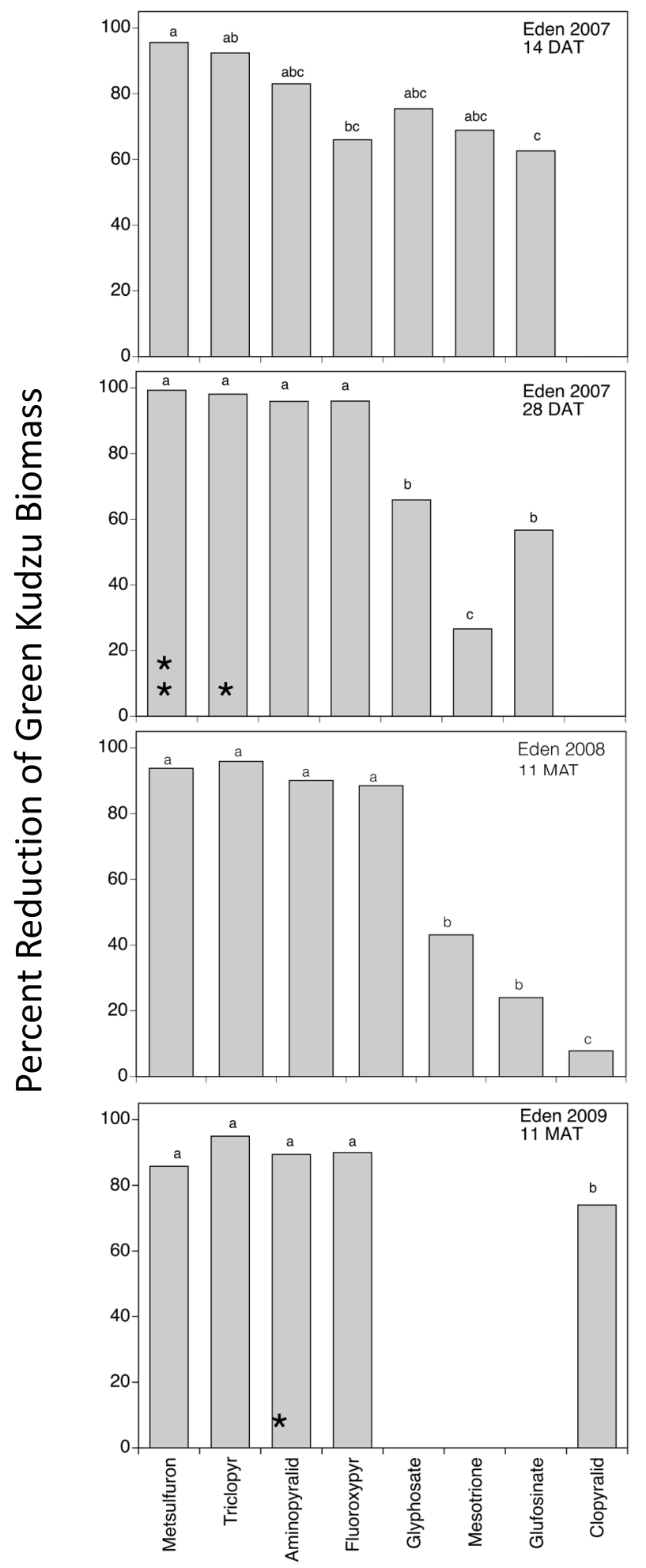

Figure 1. Suppression of kudzu after herbicide application at Eden, Mississippi. Treatments with the same letter are not significantly different at the 0.05 level. Mesotrione, glufosinate and glyphosate treatments were not continued in the second year. Clopyralid treatments began in the second year. The year refers to the year of observation. DAT and MAT indicate days after treatment and months after treatment, respectively. *Indicates one of three plots with no observed surviving, aboveground kudzu; ${ }^{* *}$ Indicates two of three plots with no observed surviving, aboveground kudzu. 
less reduction in kudzu aboveground biomass in its first season of application. Some possible reasons for the reduced control from the 2008 application compared to the 2007 application are year to year weather differences or that the competing vegetation in the second year prevented through herbicide spray coverage.

\subsection{Mound Bayou Results}

Several differences in the control of kudzu were observed at the Mound Bayou site relative to the Eden site (Figure 2). First, mesotrione and glufosinate were even less effective at Mound Bayou than the weak control they provided at Eden, with mesotrione having zero measureable effect the year following application. Also, while the level of brown-out 28 days after treatment was greater than $80 \%$ for six of the herbicides, including glyphosate, and four individual plots had zero observed green kudzu at that time, none of the treatments averaged over $65 \%$ control the following year. During 2008 substantial competing vegetation emerged in the herbicide-treated plots, particularly Johnsongrass (Sorghum halepense) (data not shown). After the second year of herbicide application the level of control improved and the same four treatments that were most effective at Eden produced greater than $90 \%$ kudzu reduction at Mound Bayou. The plots treated with the triclopyr and fluroxypyr mixture in the first year and clopyralid in the second year had statistically similar results to the other effective treatments. Glyphosate was less effective, giving only $64 \%$ suppression after two years of application.

\subsection{Grenada Results}

The Grenada site has received only one herbicide application, but the results obtained to date generally support the results from the previous two locations (Figure 3). While aminopyralid and fluroxypyr were statistically less effective than metsulfuron in immediate kudzu suppression (28 DAT), all four herbicides provided $95 \%$ or better control 11 months after the initial application. While no disturbance was observed during this testing period, it is reasonable that highway maintenance crews or Holly Springs National Forest staff may have subjected this kudzu to mowing or herbicide applications or prescribed burns in previous years. These disturbances may have undermined the vigor of the kudu at this location, thus enhancing the control provided by the herbicide treatments.

Kudzu is capable of very rapid growth, and even a small, remnant, population of kudzu after treatment has the potential to negate the prior control efforts. Thus, control guidelines emphasize the importance of constant vigilance for many years after initiation of control efforts [1]. During this extended period of control efforts, it would be prudent to include products with more than one mode of action. The effective herbicides identified in the present study include an acetolactate synthase inhibiting herbicide (metsulfuron) and several pyridine carboxylic acids (aminopyralid, clopyralid, fluroxypyr and triclopyr). These classes of herbicides are presently the first and fifth highest-ranking groups of herbicides with resistant weed populations, respectively [19]. To minimize herbicide use and the concomitant likelihood of off-target pesticide movement and non-target toxicity, it might be advisable to switch to spot applications of herbicide after an initial broadcast application or including products with other modes of action. While glufosinate and mesotrione were not highly effective in controlling kudzu in the present study and are not labeled for use in any site that commonly has kudzu infestation they were included in the present study in order to consider possible novel modes of action for kudzu control. Others have evaluated combining herbicides that, while only marginally effective alone, have significant synergistic activity [20].

In addition to alternating herbicidal modes of action, herbicide resistance could also be avoided through non-herbicidal control strategies. We observed excellent kudzu suppression within the $2 \mathrm{~m}$ wide mowed buffers around our test plots. While the mowed buffers received reduced rates of herbicides (drift from adjacent treatments) and greater than 10 cuttings per year, we have also noted significant suppression from unsprayed areas with just a single mowing per season (data not shown). Additionally, there is an ongoing effort to develop production and application methods of the fungal pathogen, Myrothecium verrucaria [21] [22] for control of kudzu. Together, these control tactics might be integrated to increase the pressure on kudzu and reduce the time required to achieve localized eradication.

The high level of kudzu control with just a single application of metsulfuron, clopyralid and triclopyr herbicides might be somewhat surprising in the context of other published reports (e.g., [14]), which suggested that these products only provided moderate suppression. Furthermore, the effectiveness of aminopyralid and fluroxypyr has not been widely documented, and kudzu does not even appear on the list of weeds controlled by the 


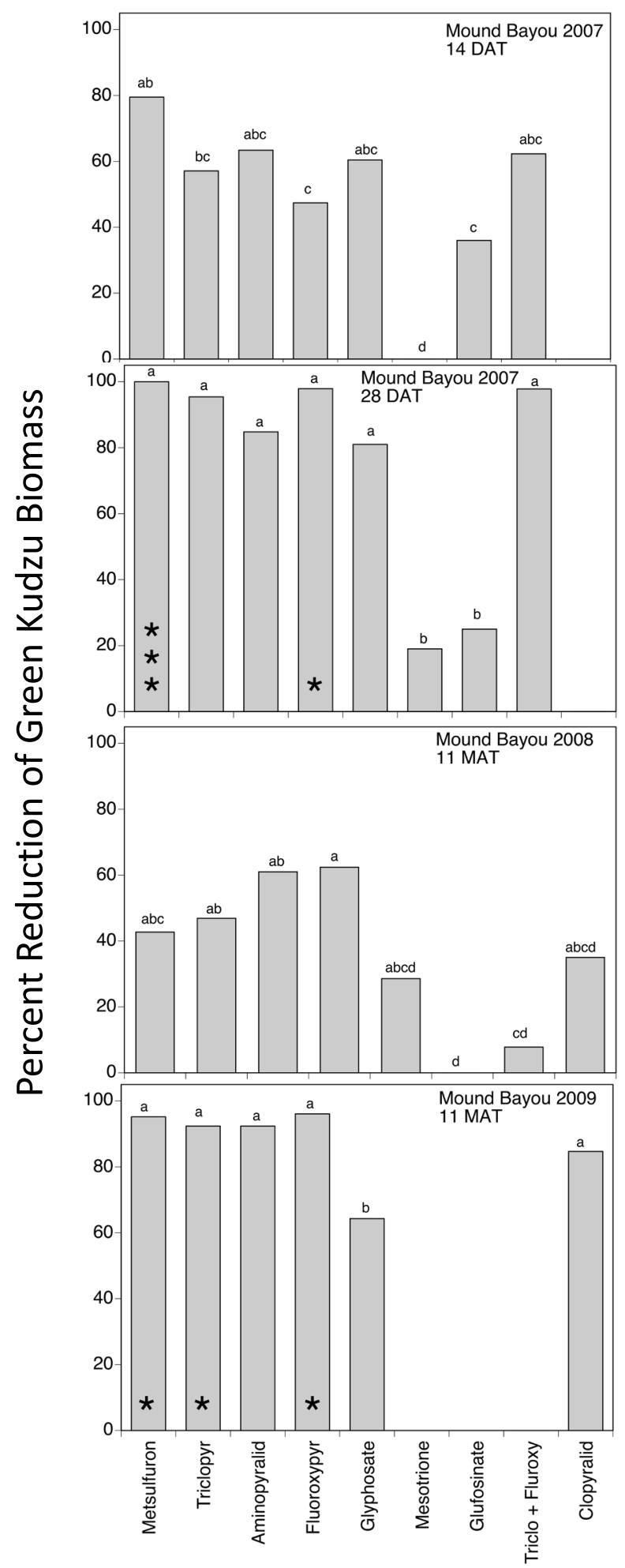

Figure 2. Suppression of kudzu after herbicide application at Mound Bayou, Mississippi. Treatments with the same letter are not significantly different at the 0.05 level. Mesotrione and glufosinate treatments were not continued in the second year. Clopyralid treatments began in the second year, replacing the fluroxypyr-triclopyr mixture treatement. The year refers to the year of observation. DAT and MAT indicate days after treatment and months after treatment, respectively. ${ }^{*}$ Indicates one of three plots with no observed surviving, aboveground kudzu; ${ }^{* * *}$ Indicates three of three plots with no observed surviving, aboveground kudzu. 


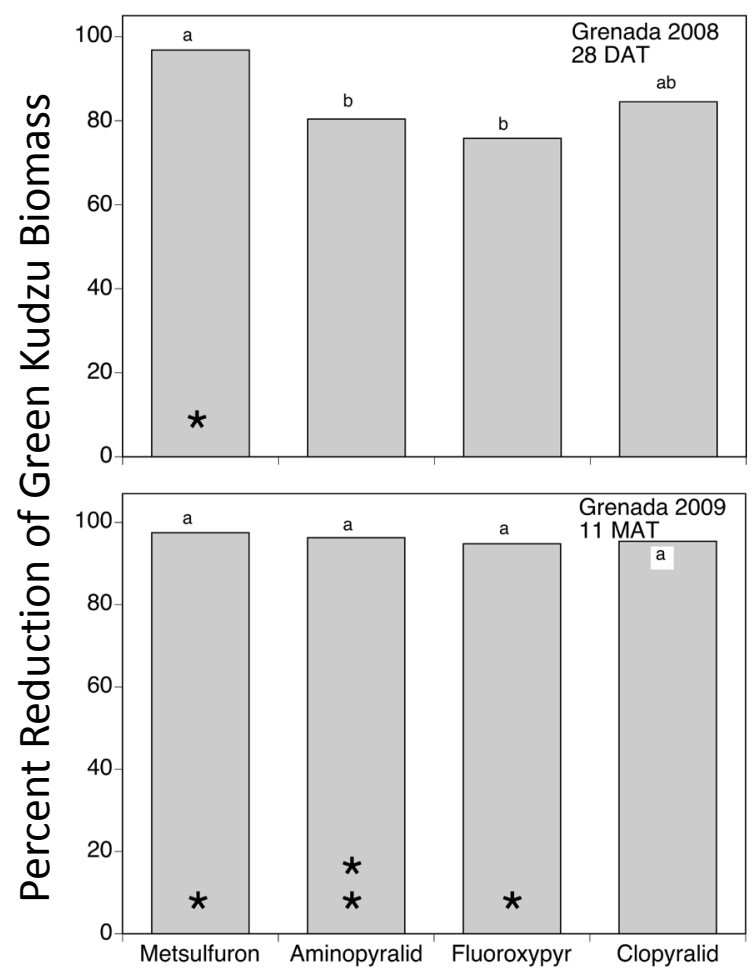

Figure 3. Suppression of kudzu after herbicide application at Grenada, Mississippi. Treatments with the same letter are not significantly different at the 0.05 level. The year refers to the year of observation. DAT and MAT indicate days after treatment and months after treatment, respectively. ${ }^{*}$ Indicates one of three plots with no observed surviving, aboveground kudzu; ${ }^{* *}$ Indicates two of three plots with no observed surviving, aboveground kudzu.

commercial formulation of fluroxypyr. It is possible that in the present study the local climacteric conditions were especially favorable for control; however, similar results were obtained at 3 locations over 2 years. The commercial triclopyr product evaluated in these studies, Remedy Ultra, was a new formulation, which might have improved the efficacy of this chemical. A more likely explanation, however, is the nearly ideal application conditions in the present study. In order to maximize reproducibility and control, all the plots were on fairly open, nearly level ground and all herbicides were applied with an ATV-mounted, high-volume boomless nozzle system. This methodology likely produced more complete and uniform coverage than might be routinely achieved with hand-held sprayers.

\section{Conclusions}

It can be concluded from the present study that a high level of kudzu suppression can be achieved very quickly. Although eradication of kudzu should not be expected from any of the tested herbicides with a single application and the threat from kudzu would still be present, the land could begin the transition to agriculture, forestry or natural systems. Another important conclusion is that there are several good alternatives to picloram and tebuthiuron for kudzu control, including relatively inexpensive products with greatly reduced application rates, fewer use restrictions, and greatly improved selectivity.

Mention of trade or commercial names is solely for the purpose of providing specific information and does not imply recommendation or endorsement by the USA Department of Agriculture.

\section{Acknowledgements}

Thanks to Laura Bennett, Benjamin Maddox, Carol Morris, Marguerite Sherman and Ken Stetina for technical assistance. Thanks to William Molin and Charles Bryson for helpful discussions. Thanks to Trent Lamastus and Tra Dubois for allowing these experiments on their land. Thanks to cooperators with the Holly Springs National 
Forest and the Mississippi Department of Transportation. Transline, RemedyUltra and PastureGard were provided by Dow AgroSciences. Touchdown HiTECH was provided by Syngenta.

\section{References}

[1] Everest, J.W., Miller, J.H., Ball, D.M. and Patterson, M.G. (1999) Kudzu in Alabama. Alabama Cooperative Extension Service Circular ANR-65, 6 p.

[2] Forseth, I.N. and Innis, A.F. (2004) Kudzu (Pueraria montana): History, Physiology, and Ecology Combine to Make a Major Ecosystem Threat. Critical Reviews in Plant Sciences, 23, 401-413. http://dx.doi.org/10.1080/07352680490505150

[3] Jurick II, W.M., Narvaez, D.F., Brennan, M.M., Harmon, C.L., Marois, J.J., Wright, D.L. and Harmon, P.F. (2008) Winter Survival of the Soybean Rust Pathogen, Phakopsora pachyrhizi, in Florida. Plant Disease, 92, 1551-1558. http://dx.doi.org/10.1094/PDIS-92-11-1551

[4] Mississippi Kudzu Coalition (2005) Kudzu Control Demonstration Brochure. Provided as Personal Communication from Alan Van Valkenburg, Mississippi Forestry Commission.

[5] Newton, C.H., Nelson, L.R., DeWalt, S.J., Mikhailova, E.A., Post, C.J., Schlautman, M.A., Cox, S.K., Bridges, W.C. and Hall, K.C. (2008) Solarization for the Control of Pueraria montana (kudzu). Weed Research, 48, 394-397. http://dx.doi.org/10.1111/j.1365-3180.2008.00660.x

[6] Britton, K.O., Orr, D. and Sun, J.H. (2002) Kudzu. In: Van Driesche, R., Ed., Biological Control of Invasive Plants in the Eastern United States, USDA Forest Service Publication FHTET-2002-04, Morgantown, 325-330.

[7] Sun, J.H., Liu Z.D., Britton, K.O., Cai, P., Orr, D. and Hough-Goldstein, J. (2006) Survey of Phytophagous Insects and Foliar Pathogens in China for a Biocontrol Perspective on Kudzu, Pueraria montana var. lobata (Willd.) Maesen and S. Almeida (Fabaceae). Biological Control, 36, 22-31. http://dx.doi.org/10.1016/j.biocontrol.2005.09.007

[8] Boyette, C.D., Abbas, H.K. and Walker, H.L. (2001) Control of Kudzu with a Fungal Pathogen Derived from Myrothecium verrucaria. US Patent No. 6274534.

[9] Miller, J.H. and Edwards, B. (1983) Kudzu: Where Did It Come From? And How Can We Stop It? Southern Journal of Applied Forestry, 7, 165-169.

[10] Miller, J.H. (1985) Testing Herbicides for Kudzu Eradication on a Piedmont Site. Southern Journal of Applied Forestry, 9, 128-132.

[11] Miller, J.H. (1986) Kudzu Eradication Trials Testing Fifteen Herbicides. Proceedings of the Southern Weed Science Society, 39, 276-281.

[12] Nelson, L.R. (2003) Kudzu Eradication Guidelines. Clemson Extension Service. http://www.clemson.edu/extfor/vegetation management/ec656.htm

[13] Harrington, T.B., Rader-Dixon, L.T. and Taylor Jr., J.W. (2003) Kudzu (Pueraria montana) Community Responses to Herbicides, Burning and High-Density Loblolly Pine. Weed Science, 51, 965-974. http://dx.doi.org/10.1614/02-142

[14] Miller, J.H. (1996) Kudzu Eradication and Management. In: Hoots, D. and Baldwin, J., Eds. Kudzu the Vine to Love or Hate, Suntop Press, Kodak, 137-149.

[15] Berisford, Y.C., Bush, P.B. and Taylor Jr., J.W. (2006) Leaching and Persistence of Herbicides for Kudzu (Pueraria montana) Control on Pine Regeneration Sites. Weed Science, 54, 391-400.

[16] Minogue, P.J., Enloe, S.F., Osiecka, A. and Lauer, D.K. (2011) Comparison of Aminocyclopyrachlor to Common Herbicides for Kudzu (Pueraria montana) Management. Invasive Plant Science and Management, 4, 419-426. http://dx.doi.org/10.1614/IPSM-D-11-00024.1

[17] US Department of Agriculture (2014) Conservation Reserve Program Statistics Monthly Summary-October 2014. Farm Service Agency, Government Printing Office, Washington DC.

[18] Weaver, M.A. and Lyn, M.E. (2007) Compatibility of a Biological Control Agent with Herbicides for Control of Invasive Plant Species. Natural Areas Journal, 27, 264-268. http://dx.doi.org/10.3375/0885-8608(2007)27[264:COABCA]2.0.CO;2

[19] Heap, I. (2015) Herbicide Resistant Weeds. http://www.weedscience.org

[20] Molin, W.T. and Lyn, M.E. (2012) Methods for Controlling Weeds Including Kudzu. US Patent No. 8338333.

[21] Boyette, C.D., Reddy, K.N. and Hoagland, R.E. (2006) Glyphosate and Bioherbicide Interaction for Controlling Kudzu (Pueraria lobata), Redvine (Brunnichia ovata), and Trumpetcreeper (Campsis radicans). Biocontrol Science and Technology, 16, 1067-1077. http://dx.doi.org/10.1080/09583150600828742

[22] Weaver, M.A., Jin, X., Hoagland, R.E. and Boyette, C.D. (2009) Improved Bioherbicidal Efficacy by Myrothecium verrucaria via Spray Adjuvants or Herbicide Mixtures. Biological Control, 50, 150-156.

http://dx.doi.org/10.1016/j.biocontrol.2009.03.007 